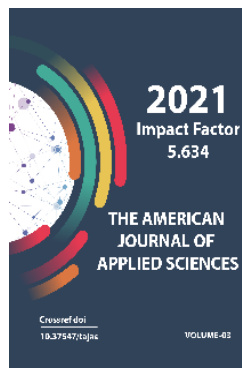

\title{
Teacher Example Compos Have A Road Map In The Heart Of The Reader
}

\author{
Lutfulla Abdukhomid Nurmahmatov \\ Lecturer, Shakhrisabz Branch Of Tashkent State Pedagogical University Named After Nizami, \\ Uzbekistan
}

\begin{abstract}
Journal Website: http://usajournalshub.c om/index,php/tajas

Copyright: Original content from this work may be used under the terms of the creative commons attributes 4.0 licence.
\end{abstract}

\section{ABSTRACT}

The article discusses the importance and relevance of methods in the formation of a trusting relationship between teacher and student in the primary grades. Therefore, the teacher must be able to use his style and methods in teaching his students. First of all, every educator should form a sense of respect for the student. In fact, he should not shout at the student, use sarcastic words, or isolate the students. Or he shouldn't try to embarrass them. These things cause the whole class to lose respect.

\section{KEYWORDS}

Student, teacher, lesson, method, lesson, communication, trust, student, educator, sarcastic words, respect.

\section{INTRODUCTION}

The student is an example of a seedling. If a good gardener cultivates this plant, it will bear fruit in the future. Therefore, the teacher must be able to use his style and methods in teaching his students. First of all, every educator should form a sense of respect for the student. In fact, he should not shout at the student, use sarcastic words, or isolate the students. Or he 
shouldn't try to embarrass them. These things cause the whole class to lose respect. Teachers need to handle situations professionally. It is important that we address issues individually, respectfully, but directly and competently. Teachers must treat every student the same. Sorting is the biggest mistake. The same set of rules should apply to all students. It is also important that the teacher is fair and consistent in dealing with students. The educator demonstrates the importance of developing confidence and developing emotional intelligence in the classroom. Respect for the educator's students is part of being a true human being. Teachers show due respect to their students.

\section{THE MAIN FINDINGS AND RESULTS}

The success of the student is the success of the teacher. A teacher who sees his students as his own children achieves better results than his students. The student feels it. It feels. According to psychologists, the teacher should listen to the student's stories, the events that are observed in him. "Don't laugh at their stories or make fun of them," "Talk about yourself. Don't just talk, walk. "These words, suggested by experts, are a compost for a teacher. The nobility of a teacher depends on his ability to listen to the stories of his students, to share his thoughts.

However, the coldness between the student and the teacher can also occur with insults without warning from the student. For example, it is an insult and injustice to simply take an argument with your spouse or someone at school and take the pain away from the student. If this is allowed, respect will be lost. The student develops distrust of the teacher along with pain. Students already understand the teacher's reaction. Consistency is necessary only when trust is established. Gaining the trust of the student depends on the perfect method of this mature teacher.

The importance of developing confidence and cultivating an emotional mind in the classroom

Teachers need to create a learning environment in which students learn to organize. The culture of communication and interaction between teacher and student, teacher and student means that their character, behavior and upbringing are reflected in practical life. A person's culture, first of all, his behavior, is reflected in his relationships with others. Educated, cultured, the teacher understands what to ask a colleague, a student, whether it is possible to address this or that issue, whether there is a need to address issues related to family relationships. One of the most important qualities of a teacher is to lift the mood of the interlocutor, to give him an optimistic spirit, to give him confidence in his own strength. It is important to note that a teacher with a real culture of behavior cannot tolerate and fight against vices such as arrogance, conceit, indifference, jealousy, and gossip.

An integral part of a teacher's communication culture is related to the culture of speech. Because speech and the words it expresses have a powerful psychological force that affects a person. It can be further enhanced not only by its content, but also by the way the speaker expresses what is being said. The teacher's dialogue is based on words and ideas, and the expression of ideas is based on the level, spiritual world and culture of each teacher. Given that the culture of communication of the teacher is necessary not 
only for interpersonal relations, but also for production, work team, community life, today it is necessary to study the character of the student, to be kind to each other. It is possible to understand the urgency of the humanization of society in the current period, when religious fanaticism is taking root. In general, improving the culture of communication has not lost its importance as a universal need. In the words of the famous writer B. Shaw: "Now that we have learned to fly like a hush in the air, to swim like a fish in water, we lack one thing - to learn to live like humans." As the protagonist of Arthur Conon Doyle's work, the famous poet Sherlock Holmes, put it, "Everyone is an unsolvable puzzle by nature." People differ in behavior and temperament, but some similarities remain. In the process of teaching and educating children, the teacher meets the criteria of universal and national traditions. Students understand the etiquette and ways of communication mainly through the teacher. A teacher is an ideal, a role model for a child for a lifetime.

Unfortunately, not all teachers are the same for children. There are, of course, teachers who, by their rudeness, discourage students from reading and offend them. There are many examples of this in life and in practice. Such teachers do not gain prestige among children, but rather harm themselves and the children. is an evaluation. In pedagogical activities, extracurricular and extracurricular activities are one of the most important areas of communication between teacher and student. There are many types of extracurricular and extracurricular activities, and it depends on the teacher to fully explain the nature of the work, the process, and the outcome in the course of communication. We will try to remind you once again of these unwritten laws of pedagogical communication.

The pedagogical process is based on our relationship with children, because the same relationship is primary in pedagogical interaction, giving each "pedagogical action" a unique personal meaning. Decorates a learning material or pedagogical requirement with a unique set of emotions Without them, the secret of the child's heart will never be understood. Always think about your relationship with your children and try to build that relationship in a purposeful way. They have a significant and regular impact on the pedagogical process, as well as on the personality of each child. Remember that in the middle of each syllabus, in the text, at the heart of the educational work plan lies the issue of your interaction with students.

Of course, it is easy to organize a conversation on the initiative of the teacher. But pedagogical communication is a complex structure, so it must be seen in terms of a certain law. In this case, the communication initiated by the student gives a good result, it fully reflects the personality of the student, provides efficiency in the implementation of pedagogical tasks. When organizing pedagogical communication, we should try to focus our speech on one child or group of students. This is as important as choosing the right methods of teaching and learning. What it means to have a clear direction of speech. First of all, it is necessary to take into account the personal characteristics of the student, his place in the classroom, in relationships with classmates. Accordingly, the main task of the teacher is to express the speech quickly, to achieve the sequence of ideas, to take into account its logicality. 
When dealing with children, we need to avoid organizing communication from top to bottom. Even very young children try to prove that they are independent. A teaching degree does not entitle a child to take the lead in dealing with children. The role of the student community in achieving this right is determined not by the official reputation of the teacher, but by his or her humanity. Interaction with children should be organized in such a way that the position of leadership is naturally derived from the logic of the pedagogical process. You need to learn to try to feel the mood in the classroom. Because if the teacher does not know the mood of the classroom, the teaching process will not be productive The teacher should try to help everyone find the secrets in their hearts and develop such skills and abilities. For example, there is a math class in the classroom.

The teacher introduces the new material to the students. A student who is interested in mathematics is listening to this lesson because he loves mathematics. The second student just sat and stared at the student who was answering. She's wondering if she's beautiful. At the same time, a third student, who doesn't like math very much but loves sports, is talking about yesterday's game to the student next to him. Another student, who didn't even understand the letter " $M$ " in math, caught sight of snow outside. If we analyze these characteristics of students one by one, we can see that the mood of the lesson is innumerable. However, in different lessons, it is necessary to approach it from today's point of view. In conversations with children, yesterday's topic can be repeated, with a seemingly insignificant change in the topic enriching the conversation with completely different information.
Therefore, it is very important to be able to control the mood in the classroom: To do this:

Every teacher needs to learn to look at themselves through the eyes of children. To do this: frequent analysis of their activities; trying to put himself in the shoes of students; Observing the lessons of colleagues and dedicating oneself to them;

Identify the shortcomings that negatively affect the work with children; open admission of mistakes, not being ashamed to say it openly when you don't know something;

Every teacher should make it a habit to talk to children in their free time; should try to determine.

Children should be asked to answer any questions and listen to what they have to say. If a student is mispronounced and finds it difficult to express his or her opinion, the teacher should respond adequately, even if the teacher's time is very tight, and warn him or her that we will discuss the rest together next time. This effect is the most important indicator of attention to the child's personality. Observations show that the main reason for students' inactivity is that teachers do not listen to children until the end. Therefore, the teacher must test himself on the following indicators. When a student speaks, don't you need to stop him?

Wouldn't it be annoying if a student said too many words and explained too much when explaining something?

Have you noticed that when a child speaks, he or she expresses that you do not agree with him or her? 
When a teacher communicates with children, it is important to try to understand their mood, to try to understand the psychological state of the classroom. It is important to remember that the mental processes of the pedagogical process are dynamic, growing and changing. This situation requires a teacher to be highly cultured in acceptance. the mood of the communication, the change in the mood of the student, on the one hand, gives the necessary information about the situation in the classroom, on the other hand, influences the choice of teaching and learning methods. Constant and regular "mental observation" in the classroom, determining the mental state of children, allows them to choose the most accurate means of interaction. Here are some suggestions on how to look or get an appointment for antique items:

Regular monitoring of children in any situation of the pedagogical process;

$>$ Monitor the lessons of colleagues and try to constantly determine the situation in the classroom;

$>$ To take into account the growth of the logic and development of students' mental state in their lessons, to identify the causes of change;

$>$ Talk to students after class and find out what caused them to change their mood during the lesson;

$>$ At the beginning of the lesson or during a personal conversation with students, try to find out what caused the change in their mood;

$>$ Development of pedagogical observation.

\section{CONCLUSION}

In conclusion, the organization of pedagogical dialogue should not be limited to pedagogical goals and objectives. This restriction allows the teacher to communicate on his or her own initiative. Dominance in his words it is not difficult to understand the meaning. "It's necessary for me. It has to do with pedagogical goals and objectives. It stems from programs and plans. "The organization of pedagogical communication" on its own initiative "severely limits the teacher's activities, leaving the student out of his or her sphere of activity. Many of our well-known educators say, "We adults, teachers, force children to do things that we enjoy, and acting on their whims is often outside the scope of our pedagogical work." Therefore, it is better to use "child initiative" rather than teacher initiative in communicating with children. Then the child will always be part of our pedagogical activity. It should also be noted that communication in the pedagogical process can not be limited to only one task, that is, information. This requires one type of communication - the exchange of information, the organization of relationships, the study of the child's personality, the interaction of adults and children, and other means. We may not be aware of one of the current trends in pedagogical communication. But the consequences will be felt the next day, and the results of education will be disrupted. To prevent this from happening, the teacher needs to study the child's personality.

\section{REFERENCES}

1. Qurbonov Sh. and others. The dream of a harmoniously developed generation-T :: «Shark», 1998, 184 p. 
2. Kuronov M. School spirituality and national education. / Monograph. -T .: Fan, 1995. -127 b.

3. Sharafuddinov O.A. Life and work of Alisher Navoi -T .: Uzdavnashr. 1984 y.

4. The child of the third millennium. Ma'rifatMadadkor, T., 2002. 7. Valikhojayev B., Vohidov R. Navoi's work is a source of inspiration. - $\mathrm{T} .: 1981 \mathrm{y} .-74 \mathrm{~b}$.

5. Sense of homeland /A.lbragimov, H.Sultonov, N.Jurayev. -T .: O'zbekiston, 1997. - $439 \mathrm{p}$.

6. Yusupova P. Pedagogy of preschool education: Faculty of preschool education of pedagogical institutes. For students. $-\mathrm{T}$ .: Teacher, 1993.-264 p.

7. Ziyoyev $\mathrm{H}$ The basis of independence and spirituality. T:. Spirituality, $1999190 \mathrm{p}$

8. Ziyoyev H. Formation of the Uzbek people. / Guliston, № 4. 1990y.

9. Zunnunov A. Excerpts from the development of pedagogical thought in Central Asia. -T .: "Science", 1996 -152 b.

10. Zunnunov A. History of Uzbek pedagogy. T .: Teacher, 1997. -272 b. 